\title{
Groundwater Quality and Soil Characterization: A Case Study at Bukit Tembaga, Kuala Nerang, Kedah
}

\author{
Nor Izzah Abdul Aziz ${ }^{1}$ and Norzila Othman ${ }^{2, *}$ \\ ${ }^{1}$ Department of Water and Environmental Engineering,Faculty of Civil and Environmental \\ Engineering,UniversitiTun Hussein Onn Malaysia. \\ ${ }^{2}$ Micropollutant Research Centre, Faculty of Civil and Environmental Engineering, UniversitiTun \\ Hussein Onn Malaysia.
}

\begin{abstract}
Soil test can be used toanalyze soil characterization. The character of soils can reflect the quality of underground water. Nowadays groundwater can be used as an alternative to drinking water. The mineral contain in soil will give an added value to the quality of groundwater.This study extracted groundwater from lot 1981, Bukit Tembaga, Kuala Nerang Kedah which was in Padang Terap district. Generally this area is classified as hilly area and surrounded by a rubber plantation. The objective of this paper is to analyze characterization of the soil in term of oxide compound, groundwater quality and correlation between chemical concentration and groundwater quality. Chemical concentration in soil was analyzed using XRF. Groundwater quality was tested by using APHA standard 2012. The parameters for groundwater sourcewere compared with the Groundwater Standard.The correlation coefficientvalue is calculated using Pearson's method. The results indicated that certain metals present in the soil and groundwater samples. The negative value of correlation coefficientproved that high concentration of metals in soil resulted to low concentration of metals in groundwater.
\end{abstract}

\section{Introduction}

Soil comprises of all the materials in the surface layer of the earth's crust that are loose enough to be moved by spade or shovel [1]. Soil is substantially different from one place to another place in the world. The changes of the soil are caused by chemical, physical and biological processes [2]. These processes can be intensified by the action of the climate, relief, parent material, living organisms and time, which are the main factors of soil formation [3].

The transformation of rock into soil wasdesignated as soil formation. Soil forming factors are climates, organisms, parent material, topography and time [4]. Every soil originally formed from parent material, a deposit at the earth's surface. The material could have been bedrock that weathered in place or smaller materials carried by flooding rivers,

\footnotetext{
*Corresponding author: norzila@uthm.edu.my
} 
moving glaciers, or blowing winds. Over time, sun, water, wind, ice, and living creatures help transform, or change, the parent material into soil [1].

In the soil formation, some major elements exist depend on nature of the process. These elements including silicon ( $\mathrm{Si}$ ), aluminium ( $\mathrm{Al})$, calcium $(\mathrm{Ca})$, Magnesium $(\mathrm{Mg})$, Iron ( $\mathrm{Fe})$, Sodium (Na), Pottasium (K), Manganese (Mn), Phosphorus (P) and titanium in soils which are mainly release from parent mostly overlain by igneous or sedimentary rocks [5].Therefore soil composition and formationwill give effect to land use and local culture indirectly.

Groundwater is the water found underground in the cracks and spaces in soil, sand and rock. It is stored in and moves slowly through geologic formations of soil, sand and rocks called aquifers [6]. Groundwater and source of groundwater quality can be effected by type of soil, human activity, climate relief and time[7-10].Underground water sources are an alternative to the drinking water supply in Malaysia. Despite that, not all underground water can be used as sources of drinking water supplies. Groundwater quality problem are typically associated with high hardness, high salinity and elevated concentration of iron, manganese, ammonium, fluoride and occasionally nitrate and arsenic [11].The contamination of groundwater by heavy metals was triggered as threats to public health [12-13]. Groundwater and soil pollution in Malaysia for the pastfew yearshas not been identified as key environmental issue in Malaysia as compare to many water pollution problems [13-14]. This is true since not many cases of environmental and human health incidents have been reported. However with increasing demand for agricultural andalternative drinking water, groundwater and soil vulnerability has become an important environmental and human health issues [7].

The objective of this paper is to analyze characterization of the soil compound and groundwaterparameter. The correlation between oxide metal from soil and in the groundwaterwill be calculated.

\section{Study area}

The study area was located at lot 1981, Bukit Tembaga Utara, MukimTemak, Kuala Nerang Kedah which is in Padang Terap District as shown in Fig. 1. According to Mineral and Geoscience Department of Malaysia, this area is characterized by the presence of the following major soil types namely ereniterock and argillite. Geology of the area is underlain by rocks of Triassic age (230 - 250 million years ago) in Semanggol Formation. Generally this area is classified as hilly area. The western part of this area consists of hose layers of shale rock, mudstone, siltstone andalluvial sediments [8].This area is surrounding by rubber plantation. Although rubber can be planted on variety of soil types, but it grows best on deep (minimum $2 \mathrm{~m}$ ), well drained and well aerated, permeable soils of loamy or sandy clay texture (clay content $>20 \%$ ) [15].

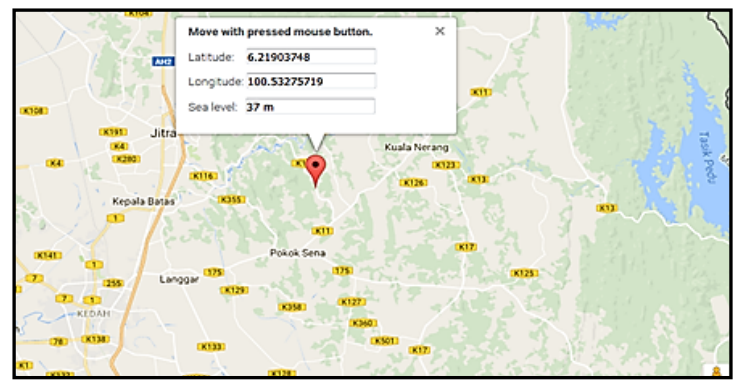

Fig.1.Map of lot 1981, Bukit Tembaga Utara. 


\section{Methodology}

\subsection{Soil sampling}

Random sampling was used in soil sampling. Refer to EPA 1984 and EPA 1989 for a random number table and guidelines on selecting sample coordinates. The arbitrary selection of sample locations requires each sample location to be chosen independently so that results in all locations within the area of concern have an equal chance of being selected [15-16] as in Fig. 2.

This composited was comprised of 10 cores of soil from sampling area $250 \mathrm{ft}^{2}$. Every cores wastaken at the depth for each station of $1.2 \mathrm{~m}$ and $2.4 \mathrm{~m}$, respectively. Sample A namely for the depth $1.2 \mathrm{~m}$ and sample B for the depth of $2.4 \mathrm{~m}$ [16].

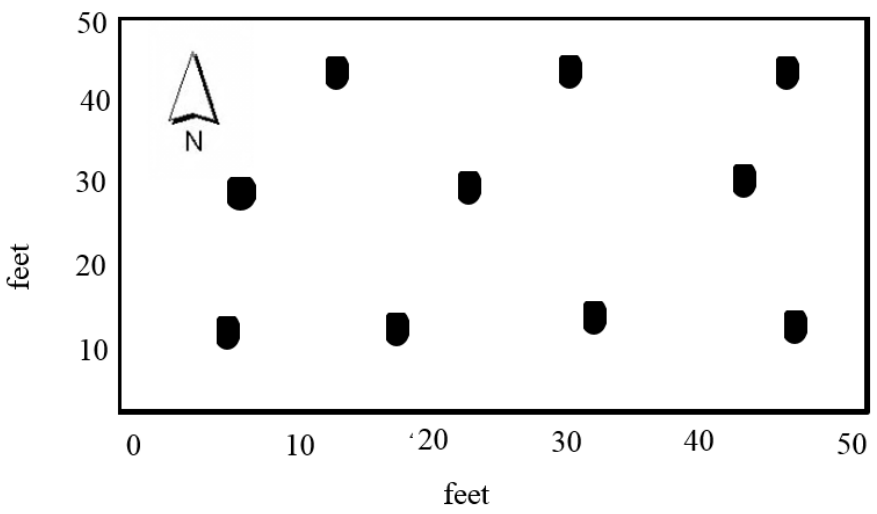

Fig.2. Random Soil sampling area and distribution [16].

Soil sample was taken from the surface to the depth of $15 \mathrm{~cm}$ in cropping situation. The slices are placed in a clean plastic pail then mix thoroughly. The mixer was spread out on clean paper to dry in open air then crushed and ground to powder form before being analyzed by a X-Ray Fluorescent (XRF) machine [10].AnX- Ray Fluorescent Analysis is to determine the chemical composition of the soil. Prior to analysis $6.0 \mathrm{~g}$ of soil were mixed homogeneously 4.0g binder wax and compressed into pallet using PE-Man Hydraulic press. Three samples were used for each depth per station.

\subsection{Groundwater Sampling}

Groundwater sampling have directed towards evaluating water quality of aquifers for water supply purpose[13].A total of 16groundwater samples were collected by grab sampling within 4 weeks from May to June 2016 [8]. Samples of groundwater were collected from groundwater tube well located atlot 1981, Bukit Tembaga Utara, MukimTemak, Kuala Nerang Kedah. The groundwater is located at foothill of Bukit Tembagaon the contour of $20 \mathrm{~m}$ to $30 \mathrm{~m}$. The well is $112 \mathrm{~m}$ depth and $200 \mathrm{~m}$ radius andsurrounded by rubber tree plantation[8]. All sampling bottles were acid washed prior for sampling[13].

Groundwater was allowed to run for 30 minutes in order to remove stagnant water and allow representative groundwater to be sampled [9]. Sample bottle were fully filled with water samples to ensure the elimination of air bubbles and organic particulate matter entrapped in the bottles. Groundwater samples were filtered through $0.45 \mu \mathrm{m}$ membrane cellulose nitrate filter paper using glass filtration unit [14]. The filtrates were acidified with 
HNO3 [15]. Then water samples were stored at $4^{\circ} \mathrm{C}$ before further analysis. Parameter analyzed as tabulated in Table 1.

Table 1.Method used for water parameter test [9].

\begin{tabular}{|c|c|c|}
\hline Parameter & Unit & Method \\
\hline Turbidity & NTU & APHA 2130B \\
\hline $\mathrm{pH}$ & - & APHA 4500+H \\
\hline Chloride & $\mathrm{mg} / \mathrm{L}$ & In house method based on APHA 4110B \\
\hline Magnesium $(\mathrm{Mg})$ & $\mathrm{mg} / \mathrm{L}$ & APHA 3120B \\
\hline Sodium $(\mathrm{Na})$ & $\mathrm{mg} / \mathrm{L}$ & APHA 3120B \\
\hline Total dissolved Solid & $\mathrm{mg} / \mathrm{L}$ & APHA 2540C \\
\hline Pottasium $(\mathrm{K})$ & $\mathrm{mg} / \mathrm{L}$ & APHA 3120B \\
\hline Calcium $(\mathrm{Ca})$ & $\mathrm{mg} / \mathrm{L}$ & APHA 3120B \\
\hline Silica & $\mathrm{mg} / \mathrm{L}$ & APHA 4500 $-\mathrm{SiO} 2 \mathrm{C}$ \\
\hline
\end{tabular}

\section{Results and Discussion}

\subsection{Soil Analysis}

The soil sampleswere enriched with high concentration of Silicon dioxide $\left(\mathrm{SiO}_{2}\right)$ $(43.90 \%)$ and Aluminium Oxide $\left(\mathrm{Al}_{2} \mathrm{O}_{3}\right)(12.10 \%)$. High concentration of $\mathrm{SiO}_{2}$ and $\mathrm{Al}_{2} \mathrm{O}_{3}$ were contributed by clay minerals such as vermivulate and illite [16]. Another factor influence the soil characteristic is due to the study areaunderlain by rocks of Triassic age (230 - 250 million years ago) in Semanggol formation, the chemical content in the soil is influenced by the type of rock especially parent material [1]. Other metals like iron, titanium, magnesium and zirconium present in low concentration. The chemical content in the soil at twodifferent depths were not significantly different. The result of all oxide metals as in Table 2 .

Table 2. Chemical concentration in soil at lot 1981, Bukit Tembaga Utara.

\begin{tabular}{|l|c|c|}
\hline \multicolumn{1}{|c|}{ Parameter } & $\begin{array}{c}\text { Sample A } \\
\text { Concentration (\%) }\end{array}$ & $\begin{array}{c}\text { Sample B } \\
\text { Concentration (\%) }\end{array}$ \\
\hline Silicon dioxide $\left(\mathrm{SiO}_{2}\right)$ & 43.90 & 48.00 \\
\hline Aluminium Oxide $\left(\mathrm{Al}_{2} \mathrm{O}_{3}\right)$ & 12.10 & 13.00 \\
\hline Carbon $(\mathrm{C})$ & 10.00 & 10.00 \\
\hline Potassium oxide $\left(\mathrm{K}_{2} \mathrm{O}\right)$ & 2.35 & 3.15 \\
\hline Iron Oxide $\left(\mathrm{Fe}_{2} \mathrm{O}_{3}\right)$ & 2.33 & 1.79 \\
\hline Titanium Oxide $\left(\mathrm{TiO}_{2}\right)$ & 0.70 & 0.70 \\
\hline Magnesium Oxide $\left(\mathrm{MgO}_{2}\right)$ & 0.39 & 0.57 \\
\hline Zirconium dioxide $\left(\mathrm{ZrO}_{2}\right)$ & 0.24 & 0.14 \\
\hline LOI (loss of ignition) & 27.99 & 22.65 \\
\hline
\end{tabular}

*Note:

1. Sample A is for $1.2 \mathrm{~m}$ depth

2. Sample B is for $2.4 \mathrm{~m}$ depth 


\subsection{Groundwater Analysis}

Analysis of groundwater samples as tabulate in Table 3.The result of the analysis groundwater (raw water) is compared with Groundwater Standard and Ministry of Health Standard.According to groundwater standard the value of the groundwater in the range of the standard but certain essential minerals are present in low concentration.

The Ministry of Health Standard for raw water quality criteriawas adopted to ensure the quality of groundwater is applicable as source of drinking water after being treated [17].It is noted that the groundwater has high possibility to be used as drinking water due to the present of some mineral such as calcium, magnesium, zinc, iron, sodium, potassium, chloride, nitrates, sulphates and fluoride as essential mineral to human health [18-20]. Nevertheless, the values of minerals are still low compare to the values following $\mathrm{MOH}$ standard. Therefore, an extensive treatment is needed to further increase the minerals content in the groundwater. Adopted of sorption technology in removing and increasing essential elements is among choice of technology for groundwater treatment [21].

Table 3. Result for groundwater from Bukit Tembaga.

\begin{tabular}{|c|c|c|c|c|}
\hline Parameters & Unit & $\begin{array}{l}\text { Groundwater } \\
\text { for study area }\end{array}$ & $\begin{array}{c}\text { Ground } \\
\text { water Quality } \\
\text { Standard } \\
\text { [raw water } \\
\text { criteria] }\end{array}$ & $\begin{array}{c}\text { MOH } \\
\text { Drinking } \\
\text { Water } \\
\text { standard }\end{array}$ \\
\hline $\begin{array}{l}\text { Microbiological } \\
\text { Escherichi Coli }\end{array}$ & $\begin{array}{l}\text { MPN/ } \\
100 \mathrm{ml}\end{array}$ & absent & $0 / 100 \mathrm{~mL}$ & $0 / 100 \mathrm{~mL}$ \\
\hline $\begin{array}{l}\text { Physical } \\
\text { Turbidity } \\
\text { Colour } \\
\text { Total dissolved solid } \\
\text { (TDS) } \\
\text { Dissolved Oxygen (DO) }\end{array}$ & $\begin{array}{l}\mathrm{NTU} \\
\mathrm{TCU} \\
\mathrm{mg} / \mathrm{L} \\
\mathrm{mg} / \mathrm{L}\end{array}$ & $\begin{array}{c}98.23 \\
10 \\
208 \\
\\
9.50\end{array}$ & $\begin{array}{c}1000 \\
300 \\
1500 \\
\text { n.a }\end{array}$ & $\begin{array}{c}5 \\
15 \\
1000 \\
\text { n.a }\end{array}$ \\
\hline $\begin{array}{l}\text { Chemical } \\
\mathrm{pH} \\
\text { Alkalinity } \\
\text { Chloride }(\mathrm{Cl}) \\
\text { Sulphate }\left(\mathrm{SO}_{4}\right) \\
\text { Nitrate }\left(\mathrm{NO}_{3}\right) \\
\text { Fluoride }(\mathrm{F}) \\
\text { Potassium }(\mathrm{K}) \\
\text { Sodium }(\mathrm{Na}) \\
\text { Bromide }(\mathrm{Br}) \\
\text { Calcium }(\mathrm{Ca}) \\
\text { Magnesium }(\mathrm{Mg}) \\
\text { Zinc }(\mathrm{Zn}) \\
\text { Silicon }(\mathrm{Si}) \\
\text { Iron }(\mathrm{Fe}) \\
\text { Arsenic }(\mathrm{As}) \\
\text { Stronium }(\mathrm{Sr})\end{array}$ & $\mathrm{mg} / \mathrm{L}$ & $\begin{array}{c}6.23 \\
157 \\
2.63 \\
0.75 \\
2.26 \\
0.10 \\
4.12 \\
8.62 \\
0.41 \\
31.84 \\
8.87 \\
0.13 \\
8.11 \\
\mathrm{ND}(<0.001) \\
\mathrm{ND}(<0.001) \\
0.06\end{array}$ & $\begin{array}{c}5.5-9.0 \\
\text { n.a } \\
250 \\
250 \\
10 \\
1.5 \\
200 \\
200 \\
\text { n.a } \\
\text { n.a } \\
150 \\
3 \\
\text { n.a } \\
1.0 \\
0.01 \\
\text { n.a }\end{array}$ & $\begin{array}{c}6.5-9.0 \\
\text { n.a } \\
250 \\
250 \\
10 \\
0.6 \\
200 \\
200 \\
\text { n.a } \\
\text { n.a } \\
150 \\
3 \\
\text { n.a } \\
0.3 \\
0.01 \\
\text { n.a }\end{array}$ \\
\hline
\end{tabular}

*Note

1. ND - not detected by the instrument less than the minimum detection limit reported

2. n.a- Not available 
Correlation is a statistical tool that helps to measure and analyze the degree of relationship between chemical concentration in soil and raw water parameter quantity.Pearson's method was used to find the correlationcoefficient $(r)$ as in Table 4.

Table 4. The correlation between soil chemical and groundwater (raw water) content.

\begin{tabular}{|c|c|c|c|}
\hline Formula & Soil (\%) & Raw water $(\mathbf{m g} / \mathbf{L})$ & $\boldsymbol{r}$ \\
\cline { 1 - 3 } Silicon dioxide $\left(\mathrm{SiO}_{2}\right)$ & 45.95 & 0.75 & \multirow{2}{*}{$\mathbf{- 0 . 2 7 5 2}$} \\
\cline { 1 - 3 } Potassium oxide $\left(\mathrm{K}_{2} \mathrm{O}\right)$ & 2.75 & 4.12 & \\
\hline Magnesium Oxide $(\mathrm{MgO})$ & 0.48 & 8.87 & \\
\hline
\end{tabular}

The value of correlation coefficient is -0.2752 , and it was consider weak correlation value. The present of high concentration of oxide metal in the soil resulted to low concentration the ions in the groundwater.

\section{Conclusion}

It could be concluded that the soil at the study area contain major and minor element of metals. The concentration of the major and minor element oxides has been notice with change in depth. Results of groundwater quality show that all the valuesare within the Ministry of Health Drinking for Groundwater Standard except for turbidity and Calcium (Ca). Significant metals that present in soil also available in groundwater analyzed.

This research was supported by Office for Research, Innovation, Commercialization, Consulting Management (ORICC), UniversitiTun Hussein Onn Malaysia (UTHM) under project vot; U569 and Post graduate Centre.

\section{References}

[1] S.K Sanjay,Core principles of soil mechanis. ICE publishing, London, (2014)

[2] J.Mark and J. Breitenstein, The relationship between soil and water: How soil amendments and compost can aid in salmon recovery, King Country department of Natural Resources. Washington. (1999)

[3] W. Chestworth. Encylopedia of soil science.Springer publishing (2008)

[4] A.S Vladychenskiy. Genesis of solis and factors of the soil formation, Environment Structure and Function: Earth System,23-33,(2004).

[5] H. Jenny and R. Amundson, Factor of soil formation: A system of quantitative pedology,McGrawHill, New York, (2005)

[6] S. N Zakir, L. Ali, S. A Khattak, Variation in major element oxide with time in the soils of Peshawar Basin: Their comparison with the normal agriculture soil,Journal of Himalayan Earth Sciences, 46(2), 35-48, (2013)

[7] R. Frank and J.E.D Spellman,The drinking water handbook, USA: Taylor \& Francisgroup, (2012)

[8] A.F Mohamed, W. Y. W. Yaacob, M.R Taha and A.R Samsudin,Groundwater and soil vulnerability in the Langat Basin Malaysia,European Journal of Scientific Research, 27, 628-635, (2009)

[9] M. Mustaza and M. Muhammad.Perakuan jenis tanah dan punca air bagi Mukim Temak, Padang Terap ,Jabatan Mineral dan Geosains Malaysia, (2015)

[10] Water Environment\& APHA, Standard Methods for the Examination of Water and Wastewater Part 1000, (2012). 
[11]B. Musta, H. Fitria, W.Soehady,S. Tahir. Geochemical characterization of volcanic soils from Tawau, Sabah, Bulletin of the Geological Society of Malaysia, 54, 33-36 (2008).

[12]N.Othman and S. Asharuddin.CucumisMelo Rind as Biosorbent to Remove Fe(II) and Mn(II) From Synthetic Groundwater Solution, Advanced Material Research, 795,260265, (2013)

[13]N. Othman, S. Mohd-Asharuddin, M-F-H Azizul Rahman. An overview of fruit waste as sustainable adsorbent for heavy metal removal,Applied Mechanics and Material, 389,29-35, (2013)

[14]J.M.C Weaver, L. Cave, A.S Talma,Groundwater sampling, Water Research Commission, Republic of Soth Africa,(2007)

[15]H. Jenny,Factors of soil formation, Dovers publication New York, (2005)

[16]W, Verheye, Growth and production of rubber, Encylopedia of life support system (EOLSS), (2010)

[17]US, EPA. Soil Sampling Standard Operating Procedure: August 1997 Achive Document, (1997)

[18] Ministry Of Health, Malaysia: Kuala Lumpur. (2004)

[19]K.Kabilan, K.Mushilan and R.Sivaneswari,Study on the contents of bottled mineral water of various brands in Malaysia,J. of Natural Sciences Research, 2(4),(2012)

[20]N. Othman, A. Che-Azhar and Suhaimi, A, Zinc removal using honewdew rind,Advanced Mechanics and Material, 680, 150-153, (2014)

[21] N. Othman, Y.S. Kueh, M-F-H Aziziul-Rahman and R. Hamdan.Watermelon rind a potential adsorbent for zinc removal,Applied Mechanics and Material ,680, 146-149. (2014) 